Georgetown University Law Center Scholarship @ GEORGETOWN LAW

2003

\title{
Law and Force After Iraq: A Transitional Moment
}

Jane E. Stromseth

Georgetown University Law Center, stromset@law.georgetown.edu

This paper can be downloaded free of charge from:

https://scholarship.law.georgetown.edu/facpub/1683

97 Am. J. Int'I L. 628-642

This open-access article is brought to you by the Georgetown Law Library. Posted with permission of the author. Follow this and additional works at: https://scholarship.law.georgetown.edu/facpub

Part of the International Law Commons 
essential public goods, and the aggravation of inequality in some places and the failure of growth in others. When the sources of threats are seen as lying beyond the reach of public policy or the political capacity to raise and apply the resources necessary for their amelioration, one tends to focus on those symptoms that can be addressed with familiar means. A second factor, linked to the first, is the obstacle of ideology. Those committed to shrinking the capacity of governments to mitigate market failures, protect the vulnerable, and monitor private actors-those, in short, who disparage public authority-are poorly equipped to serve as the architects of a global governance system able to reduce the nihilistic impulse by helping to drain its sources.

In terms of the global, not just the American, interest, there was a case for regime change in Iraq. But outside the framework of the United Nations, the change could not be accomplished in a way that would be widely perceived as legitimate. Without that perception, it has proven very difficult to marshal the human and material resources required to minimize the humanitarian fallout of invasion and occupation and to establish the trusteeship the country requires if it is to be positively transformed by the experience. Above all, Iraq demonstrates the harmful absence of effective governance institutions based on a historically unparalleled partnership of the major states. Having flexed its muscles in Iraq, the United States has added to the capital available for drawing regional powers into the creation of an institution that would prescribe standards of responsible behavior applicable to all states and monitor and induce compliance. For after the Iraq wake-up call sent to other nations by the United States, an offer of self-restraint, that is, a willingness to compromise on tactics and strategies and even some ends, adds value to all of Washington's other leadership assets.

Not long after $9 / 11$, in a private meeting with academic leaders, a high official of the U.S. government rejected the charge that the Bush administration's policy was peculiarly unilateral in its approach to international relations. "Look at all the coalitions we have formed," the official said. "We are not opposed to multilateralism [as such]; what we oppose is lowest common denominator multilateralism." ${ }^{18}$ It is clear that the world now requires decisionmaking processes more frankly hierarchical, less sensitive to the claims of sovereignty, and, as a likely consequence, more decisive and expeditious than has been the norm within the United Nations framework. But it is equally clear that those processes cannot possibly be constructed, whether within or without that framework, if the United States or anyone else treats its preferences as the only denominator.

TOM J. FARER*

\section{LAW AND FORCE AFTER IRAQ: A TRANSITIONAL MOMENT}

What impact will the Iraq war of 2003 have on international law governing the use of force and on the future of the United Nations Security Council? Some commentators have proclaimed that the military intervention led by the United States amounted to the "death" of the UN Charter and the end of "the grand attempt to subject the use of force to the rule of law." The Security Council's failure to reach agreement-in the face of French-U.S. antagonisms—-spells the end, they argue, of an effective Council role in addressing major threats

\footnotetext{
18 The author was present at this not-for-attribution meeting.

" Of the Board of Editors.

${ }^{1}$ Michael J. Glennon, Why the Security Council Failed, FOREIGN AFF., May/June 2003, at 16-18, 24. The Iraq war in the face of a deeply divided Security Council was the culmination, Glennon argues, of earlier trends that eroded the UN Charter. Id. at 22-23. Anthony Arend also contends that "[f] or all practical purposes, the UN Charter framework is dead." Anthony Clark Arend, International Law and the Preemptive Use of Military Force, WASH. Q., Spring 2003 , at 89,101 .
} 
to peace and security. ${ }^{2}$ My own view is that it is premature to pronounce the "death" of the UN Charter or to give up on future prospects for Security Council agreement on the use of force. We are, nevertheless, at a difficult and precarious transitional moment in the international legal system governing the use of force, and the stark tensions reflected in the differences over Iraq are symptomatic of hard problems that may persist for the foreseeable future. Both the rules and the system need refining and reform. Success in doing so will require imagination and much greater willingness by policy makers to consider law's potential role, not as a barrier to necessary action, but as a means to enhance global security in the face of emerging threats. In seeking such reform, it will be important to build upon the realism of the Charter's founders, who combined rules governing the use of force with a clear commitment to credible enforcement action in response to threats to peace and security.

Without question, the stark disagreements between key Security Council members over how to respond to Iraq's violations of Security Council resolutions-during the 1990s and culminating in the 2003 war-do represent significant challenges for international law and institutions. But, as I will argue, the UN Charter still provides a viable and stabilizing framework for addressing threats to peace and security. It is far too early to announce the death of the UN Charter law regarding the use of force, for three reasons.

\section{RESOlUtion 1441 IN Light OF EARLIER PRACTICE}

First, the question of legal authority for using force in Iraq is a much closer one than is sometimes acknowledged. True, the Iraq war was not explicitly authorized by the Security Council as its failure to adopt the ill-fated "second resolution" made clear. ${ }^{3}$ Nor was there an actual or imminent armed attack by Iraq that would place a forcible response clearly within well-accepted parameters for self-defense. ${ }^{4}$ However, based on the language of Security Council Resolution 1441 and the resolutions and practice that preceded it, the United States and its allies could plausibly argue that the Security Council had acknowledged the seriousness of the situation and had recognized-or at least had agreed to disagree over-the legal theory that force could be used in response to Iraq's "material breach" of the disarmament obligations imposed by the Security Council after the 1991 Gulf war. The story on this issue, in any event, is a complicated one.

The United States and Britain maintained throughout the 1990s that Iraq's clear failure to comply with the Gulf war cease-fire terms in Resolution 687 constituted a "material breach" that reactivated Resolution 678's authorization to use force. ${ }^{5}$ Invoking this theory, the United

\footnotetext{
${ }^{2}$ Glennon, supra note 1, at 18-21, 25-26. The Security Council's disagreement over Iraq, Glennon argues, reflects deeper structural, political, and cultural differences that will continue to prevent Council unity in the future.

${ }^{3}$ The United States, Britain, and Spain withdrew the so-called second resolution in the face of a French threat to veto it and a broader lack of support. Even the second resolution fell short of an explicit authorization of force. Itwould, however, have affirmed that Iraq had failed to take the final opportunity to disarm afforded by Resolution 1441. See U.S.-British Draft Resolution Stating Position on Iraq, N.Y. TimES, Feb. 25, 2003, at A14.

${ }^{4}$ Neither the Lnited Kingdom nor Australia invoked self-defense as a legal justification for military action against Iraq. See UK Attorney General Lord Peter Henry Goldsmith, Legal Basis for Use of Force Against Iraq (Mar. 17, 2003), available at<http://www.ukonline.gov.uk>; see also the Australian Attorney General's Department and the Department of Foreign Affairs and Trade, Memorandum of Advice on the Use of Force Against Iraq (Mar. 18, 2003), available at<http://www.smh.com.au/articles/2003/03/19/1047749818043.html>. Nor did the United States invoke its inherent right of self-defense under Article 51 of the UN Charter in the legal justification it submitted to the UN Security Council. Letter Dated 20 March 2003 from the Permanent Representative of the United States of America to the United Nations Addressed to the President of the Security Council, UN Doc. S/2003/351 (2003) (arguing that " $[t]$ he actions being taken are authorized under existing Council resolutions, including its resolutions 678 (1990) and 687 (1991).”). It is significant that despite references to preemption in President Bush's speech to the nation on the eve of war, the United States declined to present such a legal rationale to the Security Council.

${ }^{5}$ See Jules Lobel \& Michael Ratner, Bypassing the Security Council: Ambiguous Authorizations to Use Force, Cease-Fires and the Iraqi Inspection Regime, 93 AJIL 124, 150-52 (1999); Ruth Wedgwood, The Enforcement of Security Council Resolution 687: The Threat of Force Against Iraq's Weapons of Mass Destruction, 92 AJIL 724 (1998)
} 
States and Britain-joined by France-used force against Iraq in $1993 .{ }^{6}$ In 1998, after the Security Council found Iraq in "flagrant violation of resolution 687," the United States and Britain again acted on this theory. ${ }^{7}$ To be sure, other Security Council members raised challenges to this view, and the question whether a "material breach" by Iraq gave a coalition of willing states a right to use force to disarm Iraq was a hotly debated issue in the negotiations over Resolution 1441. The United States and Britain sought a resolution that would maximize the chances of effective coercive diplomacy to disarm Iraq and that would not require a second resolution to authorize force. France sought to avoid "automaticity" regarding potential use of force and worked to ensure an additional Security Council opportunity to determine what response should follow from Iraqi noncompliance.

Adopted unanimously, Resolution 1441 was a welcome development after the debilitating divisiveness that plagued multilateral diplomacy toward Iraq during the mid-and late 1990s and eroded the Security Council's credibility. Resolution 1441 offered Iraq "a final opportunity to comply with its disarmament obligations" and "set up an enhanced inspection regime with the aim of bringing to full and verified completion the disarmament process" established by Resolution 687 and subsequent Council resolutions. ${ }^{8}$ But it was the clear U.S. threat to disarm Saddam Hussein by force if necessary that provided the backbone that gave this effort at coercive diplomacy a chance. Yet, on the central legal issue of authority to use force, Resolution 1441 provided something to each of the contending camps.

Well aware of U.S. and British arguments and precedents based on their view that they possessed legal authority to use force in response to Iraqi "material breach," the Security Council expressly declared in Resolution 1441 that "Iraq has been and remains in material breach" of its disarmament obligations under Resolution 687 and that any Iraqi failures to comply with Resolution 1441 would "constitute a further material breach." ${ }^{\prime 9}$ The Resolution also recalled the Council's repeated warnings to Iraq "that it will face serious consequences as a result of its continued violation of its obligations." ${ }^{10} \mathrm{But}$, in light of French and other views against "automaticity," Resolution 1441 also provided that Iraq's failure "at any time to comply with, and cooperate fully in the implementation of, this resolution ... will be reported to the Council for assessment." ${ }^{\text {"1 }}$ Moreover, the Security Council would "convene immediately ... in order to consider the situation and the need for full compliance with all of the relevant Council resolutions in order to secure international peace and security."12

While a full public account of the understandings among Security Council members regarding Resolution 1441 has yet to be disclosed, the text of Resolution 1441 can fairly be read as an agreement to disagree over whether an additional Security Council resolution authorizing force was needed in the event of Iraqi noncompliance. French Ambassador to the United States Jean-David Levitte has recently admitted as much in recounting how he advised against introducing the "second resolution" that the British, Americans, and Spanish sought on Iraq. "Weeks before it was tabled," Ambassador Levitte has stated, "I went to the State Department and to

\footnotetext{
${ }^{6}$ Lobel \& Ratner, supra note 5, at 150-51. This use of force was in response to Iraq's obstruction of inspections and was preceded by statements by the president of the Security Council denouncing Iraq's actions as a "material breach" of Resolution 687 and warning of "serious consequences" for "continued defiance." See id. at 151; Wedgwood, supra note 5, at 727. The UN secretary-general subsequently stated that the military action "was carried out in accordance with a mandate from the Security Council under resolution 678 (1991)" and "was in accordance with the resolutions of the Security Council and the Charter of the United Nations." Transcript of Press Conference by Secretary-General, Boutros Boutros-Ghali, Following Diplomatic Press Club Luncheon in Paris on 14 January, UN Doc. SG/SM/4902/Rev.1, at 1 (1993).

${ }^{7}$ SC Res. 1205, para. 1 (Nov. 5, 1998); Lobel \& Ratner, supra note 5, at 154; see also Wedgwood, supra note 5, at 726-28.

${ }^{8}$ SC Res. 1441, paras. 1-2 (Nov. 8, 2002).

${ }^{9}$ Id., paras. 1,4 .

${ }^{10} I d$., para. 13.

"Id., para. 4.

${ }^{12} I d$., para. 12
} 
the White House to say, don't do it. First, because you'll split the Council and second, because you don't need it. Let's agree to disagree between gentlemen, as we did on Kosovo, before the war in Kosovo . . . ."13 Moreover, Resolution 1441-in the carefully worded and painstakingly negotiated paragraph 12 - expressly provided only for a Security Council meeting to "consider" Iraqi noncompliance. Nevertheless, the British, as well as other U.S. allies, viewed a "second resolution" as extremely important politically; they wanted to make a concerted final effort to achieve Council consensus, and few would dispute that express Council authorization would have been far preferable legally as well. Rather than follow Ambassador Levitte's suggestion-which no doubt would also have been preferred by many other Council members-the United States supported its key ally, Britain, in submitting the second resolution. ${ }^{14}$

To the very end, the British worked hard to make the Charter system function effectively as they sought to secure a political consensus on the Security Council, which clearly would have enhanced the legitimacy of any subsequent action. Prime Minister Tony Blair and his Foreign Secretary Jack Straw argued eloquently for Council agreement in the face of a noncompliant Iraq; a credible threat of force by a unified Security Council, they argued, offered the best chance to compel Iraqi disarmament peacefully through coercive diplomacy. But France's adamant refusal to authorize the use of force under any circumstances and U.S. unwillingness to take the newly revived inspections through another round made Blair's efforts to chart a middle course ultimately unavailing. In the end, in a powerful and eloquent speech to the House of Commons on the eve of war, Blair argued the case for military action and its consistency with the Security Council's agreed demands on Iraq and the purposes of the United Nations. ${ }^{15}$ The Council's repeated failure to stand up to Saddam Hussein's noncompliance undercut its credibility, Blair argued, and sent a dangerous message of irresolution to Saddam and other tyrants: "[T] o will the ends but not the means ... would do more damage in the long term to the UN than any other course." ${ }^{16}$ In short, those supporting the use of force, like those opposing it, viewed themselves as acting consistently with Resolution 1441 and with the purposes of the UN Charter, in spite of their inability to find common ground. And the ultimate failure to secure agreement on a "second resolution," while deeply regrettable, ${ }^{17}$ did not deprive the military action that followed of a plausible legal justification.

\section{THE CHARTER's CORE STILL HOLDS}

Despite the intense discord on the Security Council over Iraq, it is premature to announce the death of the UN Charter for a second reason as well. Whatever disagreements there may

\footnotetext{
${ }^{13}$ Jean-David Levitte, France, Germany and the U.S.: Putting the Pieces Back Together, Address at the Council on Foreign Relations 14 (Mar. 25, 2003), available at $<\mathrm{http}: / /$ www.cfr.org/ publication.php?id=5774>. In Kosovo, NATO members used force in response to the deteriorating humanitarian situation there without seeking Council authorization in the face of the publicly stated opposition of Russia and China. See Jane E. Stromseth, Rethinking Humanitarian Intervention: The Case for Incremental Change, in HUMANITARIAN INTERVENTION: ETHICAL, LEGAL, AND Political Dilemimas 234 (J. L. Holzgrefe \& Robert O. Keohane eds. 2003).

${ }^{14}$ Even that resolution, consistent with Britain's long-standing position on authority to use force under Resolution 678 in response to Iraqi "material breach" of 687 and subsequent resolutions, simply affirmed that Iraq had failed to take the final opportunity afforded by Resolution 1441 to comply with its disarmament obligations. See supra note 3 .

${ }^{15}$ Tony Blair, PM Statement OpeningIraq Debate (Mar. 18, 2003), available at<http://www.number-10.gov.uk/output/ Page3294.asp $>$.

${ }^{16} I d$. at 10 . Blair continued:

I have come to the conclusion after much reluctance that the greater danger to the UN is inaction: that to pass Resolution 1441 and then refuse to enforce it would do the most deadly damage to the UN's future strength, confirming it as an instrument of diplomacy but not of action, forcing nations down the very unilateralist path we wish to avoid.

Id.

${ }^{17}$ Whether better diplomacy could have led to Security Council agreement is a hard question to answer. See Glenn Kessler \& Mike Allen, U.S. Missteps Led to Failed Diplomacy, WASH. POST, Mar. 16, 2003, at A15; Steven R. Weisman, A Long, Winding Road to a Diplomatic Dead End, N.Y. TIMES, Mar. 17, 2003, at A1.
} 
be around the edges-and there are many-the central core of Article 2(4) is still alive. No one seriously disputes that wars of territorial expansion and conquest are unlawful under Article 2(4). This core of agreement was reflected in the Security Council's condemnation of Iraq's invasion of Kuwait in 1990 and North Korea's invasion of South Korea in $1950 .{ }^{18}$ But there is more. The Charter's norms-which permit the use of force in self-defense or if authorized by the Security Council-together represent a great advance over those of earlier historical periods in which force could be used for almost any reason. Together, these norms establish nonintervention as the default rule, with a high burden of justification on those who would use force to resolve conflicts. ${ }^{19}$ This default rule serves important stabilizing purposes: it pushes states to seek to resolve conflicts without resorting to war and it protects different cultures and communities from external intervention. Such a regime provides a positive force for global stability.

By placing the burden of justification on those who would resort to force, the law of the UN Charter plays an important function in state decision making. As the late Abram Chayes eloquently discussed, the law governing force may not yield a simple black-or-white answer, but it can "orient deliberation" and "guide within broad limits." States cannot claim a right to go to war for any reason; on the contrary, states know that they must explain and justify their actions internationally in relationship to the Charter's norms. Moreover, in democratic states at least, the knowledge that an action must be justified publicly can have important effects on the decision-making process itself. As Chayes explains based on his firsthand experience during the Cuban missile crisis: "[T] he requirement of justification suffuses the basic process of choice. There is a continuous feedback between the knowledge that the government will be called upon to justify its action and the kind of action that can be chosen." ${ }^{21}$ If anything, the need to explain and justify one's actions in relation to the Charter's norms governing force is becoming more important in building effective coalitions with allies whose domestic publics take these norms seriously-as the United States found in working with NATO allies in Kosovo $^{22}$ and in working with the British and other allies in Iraq.

The issue of justification may become increasingly important in an information age in which publics are exposed to broader arrays of critical information and are more easily mobilized. Indeed, the Charter's basic normative content-namely, the clear justification for using force if it is in self-defense or if authorized by the Security Council-seems to be well accepted and understood among informed publics. In both Britain and the United States, for example, public opinion in support of going to war against Saddam Hussein increased significantly in

\footnotetext{
${ }^{18}$ For discussion of the UN and U.S. response in the 1991 Gulf war and in Korea, see Jane E. Stromseth, Rethinking War Powers: Congress, the President, and the United Nations, 81 GEO. L.J. 597, 621-55 (1993).

${ }^{19}$ For a discussion of the nonintervention rule in the context of the debate over humanitarian intervention, see Adam Roberts, The So-Called "Right" of Humanitarian Intervention, 3 Y.B. INT'L HUM. L. 3, at 6-7, 49-51 (2000); Stromseth, supra note 13, at 247. Louis Henkin put it well: "The occasions and the causes of war remain. What has become obsolete is the notion that nations are as free to indulge it as ever, and the death of that notion is accepted in the Charter." Louis Henkin, The Reports of the Death of Article 2(4) Are Greatly Exaggerated, 65 AJIL 544, 545 (1971). Henkin was writing in response to Thomas M. Franck, Who Killed Article 2(4)? or: Changing Norms Governing the Use of Force by States, 64 AJIL 809 (1970).

${ }^{20}$ Abram Chayes, The CuBAn Missile Crisis: InTERnational Crises and THE Role of LAW 102 (1974). Chayes argues that international law operates in the following three ways to shape and orient decision making regarding the use of force: (1) law as constraint, (2) law as justification, and (3) law as organization. Law is only one factor, among many, that influences the consideration of options. As part of a state's decision-making process, law can shape and "constrain" choices, Chayes argues, not by "dictat[ing] conduct so much as orient[ing] deliberation, order[ing] priorities, guid [ing] within broad limits." Id. Law as justification involves a process of showing that a decision can be reconciled with a set of applicable norms. Finally, law as organization involves the organizational setting in which a decision occurs, including the allocation of jurisdiction and decision-making power among different actors, such as states, regional organizations, and international organizations. As Chayes writes, "institutional structures that are the product of law can be as important as rules, and more so in organizing and channeling decision." Id.

${ }^{21} I d$. at 103.

${ }^{22}$ An illuminating discussion is found in the remarks of James Steinberg, Panel on the Role of Legal Oversight in National Security Policy, 2002 Annual Meeting of the American Society of International Law, available on tape from the American Society of International Law library.
} 
the event the Security Council agreed to authorize it. ${ }^{23}$ Conversely, the absence of Security Council support can dramatically reduce the acceptance of proposed actions by skeptical audiences, as in the case of the reaction to the war in large parts of the Muslim world.

The widespread acceptance of the Charter framework-and the fact that all the major protagonists on the Security Council sought to explain and justify their actions within that framework-does not preclude violations, of course, or strong disagreements about what the Charter permits. But, in contrast to earlier eras, the need to explain and justify the use of force in relation to the Charter-and the international law of armed conflict as well-helps to limit "the scope, the weapons, the duration, [and] the purposes for which force is used."24

\section{THE SYSTEM CAN EVOLVE}

A third reason why the law of the UN Charter is not "dead" is also apparent. Particularly during the last decade, there has been an evolution in the Security Council's interpretation of the rules that shows the ability of the system to adapt. Rigid textualist interpretations of the Charter may well be dead, but it is not clear that they were ever really alive. ${ }^{25}$ The Charter itself, like the U.S. Constitution, is a living document deliberately designed by its founders to have the capacity to meet new threats to peace and security. ${ }^{26}$ Since the early $1990 \mathrm{~s}$, for instance, the Security Council has shown a marked evolution in its characterization of "threats to the peace" to include humanitarian emergencies, the overthrow of democratically elected leaders, extreme repression of civilian populations and cross-border refugee flows threatening regional security, and failure to hold perpetrators of major atrocities accountable. ${ }^{27}$ After the terrorist attacks of September 11th, the Security Council unanimously affirmed the right of self-defense in response to those attacks, just as NATO also invoked the self-defense provisions in Article 5 of the North Atlantic Treaty. ${ }^{28}$ In the case of Kosovo, the response of the

${ }^{23}$ See Mark Z. Barabak, Showdown with Iraq: The Times Poll; Many Desire U.N. Backing for War on Iraq, L.A. TIMES, Feb. 9, 2003, at 1; Martin Merzer, Unilateral Iraq Attack Losing Support; Most Americans Favor Multinational Coalition, U.N. OK, MilwaUkEE J. SENTINEL, Jan. 12, 2003, at 3A; Frank Millar, Blair Says Public Will Support War If Iraq Flouts UN, IRISH TIMEs, Jan. 14, 2003, at 9 . While this may, in some cases, reflect a preference for acting with the strong support of other countries more than a particular awareness of the UN Charter's rules, arguments about acting consistently with international law played a particularly prominent role in the public debate in Britain. See, e.g., Adam Roberts, Law: The Case For War: Adam Roberts on Why Military Action Against Iraq Can Be Legally Justified, GUARDIAN, Sept. 17, 2002, at 16; Philip Allott \& Alan Dashwood, Letter to the Editor, TimEs (London), Mar. 19, 2003 , at 23.

${ }^{24}$ Henkin, supra note 19, at 544; see also James E. Baker, When Latuyers Advise Presidents in Wartime: Kosovo and the Law of Armed Conflict, 55 NAVAL WAR COLL. REV. 11 (2002), availableat <http://purl.access.gpo.gov/GPO/LPS17060>.

${ }^{25}$ While he is insightful and provocative, I take issue, for example, with Michael Glennon's narrow reading of the scope of the Security Council's authority under Chapter VII to respond to threats to the peace. MICHAELJ. GLENNON, Limits OF LAW, PREROGATIVES OF POWER: INTERVENTIONISM AFTER KoSOVO 101-43 (2001).

${ }^{26}$ Britain's Lord Halifax in 1945 stressed the importance of giving the United Nations and its members the flexibility to deal with new situations that could not be foreseen. As he explained:

[I]nstead of trying to govern the actions of the members and the organs of the United Nations by precise and intricate codes of procedure, we have preferred to lay down purposes and principles under which they are to act. And by that means, we hope to insure that they act in conformity with the express desires of the nations assembled here, while, at the same time, we give them freedom to accommodate their actions to circumstances which today no man can foresee. We all want our Organization to have life .... We want it to be free to deal with all the situations that may arise in international relations. We do not want to lay down rules which may, in the future, be the signpost for the guilty and a trap for the innocent.

Lord Halifax, Verbatim Minutes of First Meeting of Commission I, UN Doc. 1006, June 15, 1945, in UNITED NATIONS CONFERENCE ON INTERNATIONAL ORGANIZATION SELECTED DOCUMENTS 529, 537 (1946). Moreover, rather than defining the terms "threat to the peace, breach of the peace, or act of aggression" in Article 39 of the UN Charter, the Charter's founders left it to the Security Council to make these judgments in light of concrete circumstances. RUTH RUSSELL, A HISTORY OF THE UNITED NATIONS CHARTER 464-65, 669-72 (1958).

${ }^{27}$ See Lori Fisler Damrosch, Introduction and Concluding Reflections, in ENFORCING RESTRAINT: COLIECTIVE INTERVENTION IN INTE:RNAL. CONFLICTS 12-13, 356-59 (Lori Fisler Damrosch ed., 1993).

${ }^{28}$ See SC Res. 1368 (Sept. 12, 2001), 40 ILM 1277 (2001); Statement by the North Atlantic Council, Press Release 124 (Sept. 12, 2001), 40 ILM 1267 (2001), also available at <http://www.nato.int/docu/pr/2001/p01-124e.htm>. The Security Council's affirmation of the right of self-defense in response to the September 11 th terrorist attacks was a significant development given earlier disagreements over uses of force in response to terrorist acts. See 
Security Council and the UN secretary-general to NATO's intervention is at least suggestive of the possible beginning of an emerging norm in support of humanitarian intervention in certain exceptional factual circumstances. ${ }^{29}$ A substantial majority of the Security Council rejected a resolution condemning NATO's action, recognizing the legitimacy of a use of force in support of purposes and objectives laid down in Security Council resolutions in response to an urgent humanitarian emergency.

While these developments show the capacity of the UN Charter regime to adapt and evolve, they also expose clear tensions in the system between key norms of the Charter-tensions between the Charter's human rights provisions and its norm of nonintervention, and tensions between the Security Council's failure to effectively enforce its own resolutions and the norms limiting unilateral resort to force. But the better response is not to cling to rigid conceptions of the UN Charter and declare the document dead, but rather to work, as SecretaryGeneral Kofi Annan has tried to do, to resolve and mitigate these contradictory pressures through careful evolution. ${ }^{30}$

\section{A Transitional Moment: Doctrinal and STRuCtural Challenges}

While the UN Charter remains alive, serious and difficult issues must be grappled with in the aftermath of the deep divisions over the Iraq war. We are indeed at a challenging transitional moment in the international legal system governing the use of force. The post-September 11 th conditions-which include a primary U.S. focus on counterterrorism, a unipolar world in which the United States enjoys predominant military power, and a desire among certain countries, most notably France, to counterbalance the United States-pose both doctrinal and structural challenges to the Charter system. To be sure, the UN Charter system faced numerous difficulties from the very start. ${ }^{31}$ The Security Council was effectively paralyzed by discord and stalemate during much of the Cold War. Nevertheless, the relative, though imperfect, success of the Council in reaching agreement during the 1990s created rising expectationsamong members and public opinion more broadly - that the Council could play a significant role in addressing threats to peace and security. To be effective, the Charter regime must now evolve to meet the additional doctrinal and structural challenges that emerged so starkly in the period after September 11th.

First and foremost, there is the challenge of terrorism. The attacks of September 11, 2001, made clear the fundamental security challenge posed by nonstate actors who reject the most basic rules of international law and deliberately target civilians for brutal destruction. Terrorist networks are not constrained by the norms of reciprocity so central to the international legal system. Doctrinally, the potentially lethal combination of terrorists and weapons of mass destruction requires a rethinking of the scope of the right of self-defense. In confronting possible terrorist attacks that are uncertain in time or place but potentially devastating in their consequences, the concept of anticipatory self-defense must be reexamined and updated to account for this threat and reasonable forcible responses to it. The UN Security Council affirmed the right of self-defense in response to the September 11th terrorist attacks, but some

Michael Byers, Preemptive Self-Defense: Hegemony, Equality and Strategies of Legal Change, 11 J. POL. PHIL. 171, $177-79$ (2003); Thomas M. Franck, Editorial Comment: Terrorism and the Right of Self-Defense, 95 AJIL 839 (2001).

${ }^{29}$ See Stromseth, supra note 13, at 237-38, 246-55, 271-72.

${ }^{30}$ Annan launched initiatives to encourage the Security Council to take effective action in response to severe human rights violations. See Stromseth, supra note 13, at 261-262. Nongovernmental groups have also sought ways to reconcile the Charter's human rights and nonintervention norms. See, e.g., RESPONSIBILITYTO PROTECT: REPORT OF THE INTERNATIONAL COMMISSION ON INTERVENTION AND STATE SOVEREIGNTY (2001). For an argument that the human rights and security sides of the UN should be brought together, see Anne-Marie Slaughter, $A$ Chance to Reshape the U.N., WASH. POST, Apr. 13; 2003, at B7.

${ }^{31}$ For a healthy dose of perspective from someone who has seen the United Nations up close for many years, see the interview with Brian Urquhart, Disputes Within the UN Security Council Over Its History, National Public Radio, Mar. 6, 2003. 
members seem to view the problem of terrorism as primarily a law enforcement issue. Preventing and defending against terrorist attacks certainly requires law enforcement and intelligence cooperation on a global scale, but it may also require the appropriate and selective use of military force. The United States and its allies should reexamine the concept of selfdefense and update their understanding both of the circumstances justifying resort to selfdefense and the scope of permissible action in the post-September 11 th world.

Yet, rather than initiating a more focused attempt to refine the concept of anticipatory self-defense and working with allies on how to rethink the concept of imminent attack in light of the realities of terrorism, the United States government has articulated a doctrine of preemption whose parameters are uncertain and that is potentially very broad in scope.$^{32} \mathrm{On}$ the one hand, the Bush administration's 2002 National Security Strategy grapples frankly and openly with the exceedingly difficult security challenges posed by terrorists and by rogue states that may acquire and possibly share weapons of mass destruction with terrorists, stressing the vital need to prevent these weapons from ever being used against the United States and its allies and friends. ${ }^{33}$ On the other hand, the Strategy indicates a broader and more openended willingness to use force to prevent "rogue" states from acquiring weapons of mass destruction and to preempt "hostile acts" ${ }^{34}$ and "emerging threats before they are fully formed." 35 The very uncertainty of the doctrine's scope $\mathrm{e}^{36}$ and the subjective and often precarious nature

${ }^{32}$ See President George W. Bush, Commencement Address at the United States Military Academy, West Point, June 1, 2002, 38 WEEKLY COMP. PRES. DOC. 944 (June 10, 2002), available at <http://www.whitehouse.gov/news/ releases $/ 2002 / 06 / 20020601-3 . \mathrm{html}>$ ("If we wait for threats to fully materialize, we will have waited too long .... We must take the battle to the enemy, disrupt his plans, and confront the worst threats before they emerge .... [O] ur security will require ... preemptive action when necessary to defend our liberty and to defend our lives.").

${ }^{93}$ As the Naticnal Security Strategy of the United States of America explains: "[N]ew deadly challenges have emerged from rogue state: and terrorists ... and the greater likelihood that they will use weapons of mass destruction against us, make[s] today's security environment more complex and dangerous .... We must be prepared to stop rogue states and their terrorist clients before they are able to threaten or use weapons of mass destruction against the United States and our allies and friends .... We must deter and defend against the threat before it is unleashed." NATIONAL Security STRATEGY OF THE UNITEd STATES OF AMERICA 13-14 (Sept. 17, 2002) (Section V, Prevent Our Enemies from Threatening Us, Our Allies, and Our Friends with Weapons of Mass Destruction), available at <http:// www.whitehouse.gov/nsc/nss.pdf > [hereinafter NATIONAL SECURITY STRATEGY].

${ }^{34}$ Id. at 15. The National Security Strategy argues that "[f]or rogue states," weapons of mass destruction "are tools of intimidation and military aggression against their neighbors. These weapons may also allow these states to attempt to blackmail the United States and our allies to prevent us from deterring or repelling the aggressive behavior of rogue states." Id. While "[ $\mathrm{t}]$ he United States will not use force in all cases to preempt emerging threats, nor should nations use preemption as a pretext for aggression ... the United States cannot remain idle while dangers gather." Id. As the President put it in the Introduction to the National Security Strategy: "[A]s a matter of common sense and self-defense, America will act against such emerging threats before they are fully formed."

${ }^{35}$ Introduction to id.

${ }^{36}$ The State Department legal adviser subsequently offered an interpretation of the legal basis for preemptive military action that sought to place it more clearly within parameters of anticipatory self-defense. See William $\mathrm{H}$. Taft IV, Legal Adviser, Department of State, The Legal Basis for Preemption, published by the Council on Foreign Relations, Nov. 18, 2003, available at <http://www.cfr.org/publication.php?id=5250>. Taft wrote: "The President's National Security Strategy relies upon the same legal framework applied to the British in Caroline and to Israel in 1981. The United States reserves the right to use force preemptively in self-defense when faced with an imminent threat. While the definition of imminent must recognize the threat posed by weapons of mass destruction and the intentions of those who possess them, the decision to undertake any action must meet the test of necessity. After the exhaustion of peaceful remedies and a careful, deliberate consideration of the consequences, in the face of overwhelming evidence of an imininent threat, a nation may take preemptive action to defend its nationals from unimaginable harm." Id. at 5-6 (emphasis added). But the boundaries of the Bush administration's doctrine-as articulated in the National Security Strategy and by the President and other high officials-are unclear and potentially more far-reaching. While it is true that the preemption doctrine focuses on "the particular issue of rogue states seeking to acquire WMD," Walter B. Slocombe, Force, Preemption and Legitimacy, 45 SURVIVAL 117, 124 (2003), the circumstances in which the administration envisions taking preventive military action remain open-ended: The United States may act, for instance, "before: threats have fully materialized." Condoleezza Rice, Wriston Lecture, Dr. Condoleezza Rice Discusses President's National Security Strategy (Oct. 1, 2002), available at<http://www.whitehouse.gov/news/releases/2002/ 10/print/20021001-6.html>. Rice did add some qualifications: "[T]his approach ... does not give a green lightto the United States or any other nation-to act first without exhausting other means, including diplomacy.... The threat must be very grave. And the risks of waiting must far outweigh the risks of action." But, as discussed in the National Security Stralegy, the doctrine does not require an actual or an imminent armed attack. NATIONALSECURITY STRATEGY, supra note 33 , at 15. 
of judgments about future threats have made the doctrine highly controversial, raising doubts about the reassuring nature of U.S. power in many parts of the world.$^{37}$ In its expansive form, the doctrine poses a challenge to the UN Charter framework itself ${ }^{98}$ and has the potential to be destabilizing. ${ }^{39}$ This has alarmed a number of U.S. allies rather than providing a basis for working together to update understandings of the right of self-defense-an effort that is clearly needed if the Charter framework is to remain relevant and effective in the face of today's urgent threats. At a time when terrorist networks challenge the very foundations of order and law $\rightarrow$ and the proliferation of weapons of mass destruction in the hands of rogue states poses severe threats to international stability-the United States has a stake in maintaining rules governing the use of force that can both protect American security and help to mobilize allies against those who challenge the agreed rules.

In addition to the normative challenges ahead, the Security Council faces a severe test of its credibility. The future effectiveness and durability of the Security Council will depend on its willingness to take credible enforcement action in response to threats to peace and security. If the Charter system is to serve as a bulwark against those who would potentially use weapons of mass destruction, then the Council must be prepared to enforce its demands-to stand up to those who would defy its will.

Unfortunately, throughout the later 1990s and in the immediate buildup to the 2003 war, the Council lacked collective spine on Iraq. Key Security Council members, in particular France and Russia, watered down the sanctions and inspections regimes that they themselves had agreed to put in place to contain Saddam Hussein, and their temporizing in the face of his defiance gave Saddam unwanted room for maneuver. ${ }^{40}$ Structurally, America's predominant power vis-à-vis other Council members further complicated matters, for any effective military enforcement action against Baghdad would require substantial military power, inevitably casting the United States in the leading role. That fact, coupled with Washington's clear intention to achieve regime change in Iraq, not just the disarmament of Iraq, only reinforced France's oppositionist impulses and its tendency to view the Council as a means to counterbalance U.S. power. In short, just as the United States was reluctant to be constrained by the Security Council, France and others were reluctant to authorize the United States to be the enforcer of Council resolutions. Edward Luck put it well when he said that many states "would prefer a weak Council to a strong one dominated by the United States. They are as ambivalent about American power as Washington is about international organization." ${ }^{41}$

\footnotetext{
${ }^{97}$ For a more wide-ranging survey of global public opinion in the aftermath of the 2003 Iraq war, discussing, among other things, attitudes toward the United States and its foreign policy, see Pew Research Center for the People \& the Press, Views of A Changing World 2003 (June 3, 2003), available at <http://people-press.org/reports/display. php3?ReportID=185>.

${ }^{38}$ As discussed in the National Security Strategy, the doctrine would apply even if there were no imminent armed attack. More precisely what the administration means by "imminent threat" or "grave threat" and whether the administration would be prepared to present a situation to the Security Council in the first instance, when circumstances permit, has yet to be clarified.

${ }^{39}$ See W. Michael Reisman, Assessing Claims to Revise the Laws of War, 97 AJIL 82, 89 (2003):

The danger presented by the installation of a doctrine of preemptive self-defense is systemic: if writ large and generally available in international law, it is even more likely than anticipatory self-defense to lead to greater resort to in ternational violence by lowering the threshold for unilaterally determined contingencies that warrant acts of self-defense. This potential could create an imperative for all latent adversaries to strike sooner so as to strike first, raising the expectation of violence and the likelihood of its eventuation.
}

See also Ivo Daalder, Policy Implications of the Bush Doctrine on Preemption (Nov. 16, 2002), available at <http://www.cfr.org/ publication.php?id $=5251>$ ("The doctrine of preemption ... [i]f taken seriously by others ... will exacerbate the security dilemma among hostile states, by raising the incentive of all states to initiate military action before others do. The result is to undermine whatever stability might exist in a military standoff.").

${ }^{40}$ For incisive analysis, see Edward Luck, Making the World Safe for Hypocrisy, N.Y. TIMEs, Mar. 22, 2003, at A11.

${ }^{41}$ Id.; see also Glennon, supra note 1, at 18-20. 
This dynarnic risks becoming self-reinforcing. If the U.S. attitude toward the UN Security Council is one that says, "We're doing the enforcing our way, just give us your blessing," then states like France will see the Council first and foremost as a vehicle to balance and constrain the preponderant power of the United States. But if France and others are not willing to support coercive diplomacy backed by a credible-and authorized-threat of force, then the United States will cease to turn to the Council, and the Council's role in responding to threats to peace and security will be diminished.

This dynamic, while likely to continue in light of recent trends and attitudes, does not mean that the Council inevitably will fail to find consensus in responding to particular threats to peace and security. Many issues before the Council do not directly pose competing interests of the permanent members. Even where they do, the major powers may still find it in their interests to forge an agreement. More generally, the United States will sometimes find it beneficial to seek to legitimate its preponderant power by building multilateral support for its policies using the machinery of the Council. ${ }^{42}$ Moreover, France will ultimately only undermine the very instrument it needs to play on the world stage if it uses the Security Council solely to counterbalance U.S. initiatives. In that sense, the counterbalancing dynamic may be selflimiting. Furthermore, as in Iraq, the British are likely to continue to strive to chart a middle course and find common ground-seeking a unified Council willing to ensure that its resolutions actually have some teeth-and the value of the U.S.-British alliance may induce the United States to pursue constructive diplomacy in the Security Council. But whether such efforts will succeed will depend on the interests of the leading members concerned, the particulars of the conflict at issue, the diplomatic skill of those involved, and the willingness of the major protagonists on the Council to find common ground. The Security Council's adoption of a resolution lifting the sanctions against Iraq, affirming the authority of the occupying powers and providing for a UN role was a positive development, but difficult times remain ahead. ${ }^{43}$

\section{REFINING THE RULES AND REVITALIZING THE SYSTEM}

If international rules governing resort to force are to endure, they must be built upon and reflect the realities of power and the security needs that confront states in the real world..$^{44}$ Otherwise, states that face the greatest threats will not regard the rules as consistent with their national security needs and will disregard them. Viewed from this perspective, the core rules of the UN Charter-the clear prohibition on aggressive war of territorial expansion and annexation and the default rule of nonintervention, together with the core right of individual and collective self-defense and Security Council authorization in other situations-still provide a viable legal framework if the rules are refined to take account of recent experience and emerging security threats. But the rules and corresponding institutional enforcement mechanisms must be revilalized together; indeed, the stakes are even higher today because the threats are urgent and will increasingly require cooperative action. How should this be done?

\section{Individual and Collective Self-Defense}

The UN Charter affirms "the inherent right of individual or collective self-defense if an armed attack occurs." ${ }^{45}$ The right of anticipatory self-defense in response to an imminent

\footnotetext{
${ }^{42}$ See JOSEPH S. NYE JR., THE PARAdOX OF AMERICAN POWER: WHY THE WORLD'S ONLY SUPERPOWER CAN'T Go IT ALONE 158-63 (2002).

${ }^{43}$ SC Res. 14133 (May 22, 2003) (adopted by a vote of 14-0). Nevertheless, the deep scars left by the intense discord over Iraq will take a long time to heal. See Melinda Henneberger, Weight of the World, NEWSWEEK, May 26, 2003, at 33-37.

${ }^{44}$ See Reisman, supra note 39 , at 82 ; Glennon, supra note 1, at 31 .

${ }^{45}$ UN CHARTER Art. 51.
} 
armed attack reasonably falls within that right. ${ }^{46}$ What is especially needed today is a careful reexamination of the concept of imminence as well as of "necessity" and "proportionality"in short, the scope of the right of self-defense-in response to the urgent and unconventional threats posed by terrorist networks bent on acquiring weapons of mass destruction. Rather than press an ill-defined and open-ended doctrine of preventive war, the United States should work with like-minded states and with its allies in collective security organizations to forge agreement on a robust commitment to self-defense in the context of terrorism and weapons of mass destruction.

Regional self-defense organizations would be a good place to start to conduct this diplomacy. They involve both a normative commitment to collective self-defense and an institutional structure to implement and enforce this commitment. The ANZUS alliance may be the best place to start; the alliance is small, Australia has experienced directly the harm of terrorist attacks, and agreement between the United States and Australia could serve as a springboard to seeking agreement in other alliance contexts. ${ }^{47}$ The next-or parallel-step could be to work with the British and others on a similar initiative within NATO. The OAS could be next. The UN Charter recognizes the important role of regional arrangements both for collective self-defense and for other efforts to address regional security threats, and the United States could invigorate these alliances by seeking to forge greater agreement both on normative principles and on concrete steps to combat terrorism and to respond to weapons proliferation. The United States could also work with other allies, such as Japan, ${ }^{48}$ and with other key states, such as Russia, on similar efforts. Other groupings of like-minded states, like the Group of 8 , can also serve as productive fora for advancing counterproliferation and counterterrorism initiatives. ${ }^{49}$

In contrast, if the United States persists in pressing an expansive preemption doctrine, it will have counterproductive effects. ${ }^{50}$ Advancing a high-profile doctrine of preemption makes it more difficult for some states to cooperate with the United States and has concerned even long-standing allies who otherwise are willing to help address new threats so long as they can fairly be seen as acting within the contours of self-defense. ${ }^{51}$ It would be far better for the United States to articulate a more tailored right of anticipatory self-defense focused especially

\footnotetext{
${ }^{46}$ See Oscar Schachter, The Right of States to Use Armed Force, 82 MICH. L. REv. 1620, 1634-35 (1984) (arguing that a limited right of anticipatory self-defense to imminent attack is consistent with Article 51 of the UN Charter, citing the criteria set forth by U.S. Secretary of State Daniel Webster in the Caroline case); see also ANTHONYCLARKAREND \& ROBERT J. BECK, INTERNATIONAL LAW AND THE USE OF FORCE 71-79 (1993) (discussing differing views regarding anticipatory self-defense, but concluding that it is not prohibited).

${ }^{47}$ The ANZUS security alliance originally involved Australia, New Zealand, and the United States, but today it involves active defense commitments only between Australia and the United States. In 1986, as a result of disagreement over New Zealand's stance on nuclear warships in its ports, the United States unilaterally suspended its obligations to New Zealand under the ANZUS treaty, and New Zealand's role is described as "dormant." SeeLuke Peter, New Zealand's Dormant Role in ANZUS Unchanged Since 80s-PM, CHRISTCHURCH PRESS, Sept. 20, 2001, at 3. After the September 11th attacks, Australia invoked the collective self-defense provisions of the ANZUS treaty for the first time in the alliance's fifty-year history. See australianpolitics.com, Howard Government Invokes ANZUS Treaty (Sept. 14, 2001), at<http://www.australianpolitics.com/news/2001/01-09-14c.shtml>. See Art. IV of Security Treaty (ANZUS), Sept. 1, 1951, 3 UST 3420, 131 UNTS 83 (entered into force Apr. 29, 1952).

${ }^{48}$ See Agreement between the United States and Japan concerning the Treaty of Mutual Cooperation and Security, Jan. 19, 1960, 11 UST 1632, 373 UNTS 186 (entered into force June 23, 1960).

${ }^{49}$ See, e.g., Non proliferation of Weapons of Mass Destruction, A G8 Declaration (June 3, 2003), available at <http://www.g8.fr/ evian/english/navigation/2003_g8_summit/summit_documents.html>.

${ }^{50} \mathrm{It}$ is one thing for the United States-and other states-to keep "preemption" as an option in the event of extreme circumstances that go beyond anticipatory self-defense in response to an imminent attack; it is another to make it the centerpiece of a publicly proclaimed strategic doctrine. See Michele Flournoy \& Vinca LaFleur, Quick-Stick Doctrine, WASH. POST, June 18, 2002, at A19.

${ }^{51}$ The members of NATO, the Rio Pact, and Australia under the ANZUS treaty all invoked the collective self-defense provisions of their respective alliances in response to the September 11 th attacks. See supra notes 28 and 47; Meeting of Consultation of Ministers of Foreign Affairs, Resolution on Terrorist Threat to the Americas (Sept. 21, 2001) (invoking relevant provisions of the Rio Treaty), 40 ILM 1273 (2001), also available at <http://www.oas.org/oaspage/crisis/ RC.24e.htm>.
} 
on the unique attributes and threats posed by terrorist networks, including the degree of harm as a key variable in the equation. ${ }^{52}$ As part of this effort, the United States should work with allies and other like-minded states on agreed rules for interdicting suspected shipments of weapons of mass destruction and their components to terrorist groups or their state sponsors. ${ }^{53}$ America's friends and allies will be critically important in long-term counterterrorism efforts as will be the need to articulate norms that our allies and friends can support and defend-norms that must include effective measures to prevent weapons of mass destruction from falling into the hands of terrorists. ${ }^{54}$

\section{Duties of States to Stop Terrorism}

The United States should also work to reinforce clear duties of states to combat terrorism and to prevent terrorists from acquiring weapons of mass destruction. The Security Council can play a vital role in forging such normative standards and has already made important strides. Indeed, after September 11 th, the Council used its Chapter VII authority-in Resolution 1373to impose binding obligations upon states to prevent and suppress the financing of terrorist acts, to refrain from providing any support to terrorists, to deny safe haven to terrorists, to develop effective border controls, and to bring to justice those who commit terrorist acts, among other requirements. ${ }^{55}$ Under Resolution 1373 , states must also "eliminat [e] the supply of weapons to terrorists. ${ }^{" 56}$ The Security Council established a Counter-Terrorism Committee (CTC), which consists of all the members of the Security Council, to monitor implementation of these obligations. Under the leadership of its first chair, Britain's Ambassador Jeremy Greenstock, the CTC has taken significant steps to help build the antiterrorism capacity of states ${ }^{57}$ By combining its norm-setting role with its enforcement powers and capacity-building tools, the Security Council has shown its ability to contribute to the vital project of combating terrorism. The Council's capacity both to reinforce international standards against terrorism and to require states to take concrete counterterrorism measures is a combination that can be built

\footnotetext{
${ }^{52}$ Because terrorists generally provide no warning and are not deterrable in the way that state actors might be, disrupting terrorist networks before they can attack and preventing them from acquiring weapons of mass destruction is necessary to exercising a meaningful right of self-defense. In the case of Al Qaeda, its previous attacks and clear policies indicate an ongoing plan to attack and raise a clear presumption of future attacks. More generally, because of terrorists' disregard for the rules of international law and their use of stealth and deception to attack innocents, less certainty regarding the imminence or precise time and place of their attack is needed to act in selfdefense. Working cooperatively with states, when possible, to disrupt terrorist cells on their territory nevertheless remains critically important.

${ }^{53}$ During his trip to Europe in May 2003, President Bush launched an initiative for agreed rules and procedures concerning interdiction of weapons of mass destruction in transit. See Remarks by the President to the People of Poland, May 31, 2003, available at <http://www.whitehouse.gov/news/releases/2003/05/print/20030531-2.html>. The United States is working with a number of countries on this effort, which would involve a coordinated use of national laws. David E. Sanger, Cracking Down on the Terror-Arms Trade, N.Y. TimEs, June 15, 2003, at 4.

${ }^{54}$ The more difficult issue posed by the Bush administration's "preemption" doctrine concerns the question of preemptive use of force to prevent "rogue states" from acquiring weapons of mass destruction. Here, in the absence of an inminent threat of attack, it would be hard to justify such action legally within the right of self-defense under the UN Charter as currently understood. The practical and operational challenges of preemption in this context are also considerable. See Flournoy \& LaFleur, supra note 50; Slocombe, supra note 36, at 126-27. In the case of North Korea, the United States has, in fact, emphasized its desire to work multilaterally and diplomatically to address the situation. The UN Security Council has authority, under Article 39 of the UN Charter, to take enforcement action in response to "threat[s] to the peace," although whether, in specific cases, the Council will be able to agree on appropriate action remains to be seen.

${ }^{55}$ SC Res. 1373 (Sept. 28, 2001), paras. 1-2. In Resolutions 1267, 1390, and their progeny, moreover, the Security Council has imposed sanctions on the Taliban, Osama bin Laden, and Al Qaeda. See Jane E. Stromseth, The Security Council's Counter-Terrorism Role: Continuity and Innovation, in 98 ASIL PROC. (forthcoming 2003).

${ }^{56}$ SC Res. 1373, supra note 55, para. 2(a).

${ }^{57}$ For a discussion of the CTC's work, see Eric Rosand, Security Council Resolution 1373, the Counter-Terrorism Committee, and the Fight Against Terrorism, 97 AJIL 333 (2003); Nicholas Rostow, Before and After: The Changed UN Response to Terrorism sinie September 11th, 35 CORNELL INT'L L.J. 101, 108-1 12 (2003). Spain subsequently became chair of the CTC. The CTC has a Web site that, among other things, provides a matrix of counterterrorism assistance, <http:// www.un.org/sc/ctc>.
} 
upon further: Resolution 1373 already obligates states to refrain from supplying weapons to terrorists, and it calls upon states to exchange operational information regarding the threat posed by terrorist groups seeking to acquire weapons of mass destruction. Resolution 1373 could be supplemented by agreed rules or by an additional Council resolution that requires all states to take specific concrete and effective measures to prevent terrorists from acquiring weapons of mass destruction. A reinforced Counter-Terrorism Committee could help to monitor implementation of these obligations.

\section{The Security Council and Major Conflicts}

The harder issue-in the aftermath of the discord over Iraq-remains the question of the role of the Security Council in responding to specific major conflicts and crises. The Council's ability to act effectively will depend substantially-as it always has-on the interests of the Council's major members and the dynamics and tensions among them. In deliberately placing authority in a political body that aimed to reflect the power realities of the time, the Charter's founders sought to use the military might of strong states to enforce peace. The realism behind that decision has also meant that the Security Council, during the Cold War and since, has had difficulty dealing with major conflicts in which the interests of the great powers are at stake, with only a few exceptions. Even so, the Council has played a significant role in lesser conflicts and in authorizing peacekeeping, humanitarian assistance, and postconflict reconstruction, to name just a few areas. ${ }^{58}$

During the early 1990s, the Security Council was able to agree-beginning with the 1991 Gulf war-on responses in a number of important crises. Yet during the 1990s, another trend was evident as well, namely, an increasing disconnect between Security Council mandates and the means to effectively implement and enforce them, whether in peacekeeping operations or in imposing sanctions and disarmament requirements, as in Iraq. In too many cases, members of the United Nations, including the United States, were unwilling to provide the forces or the funds needed to succeed. In still other cases, coalitions of the willing enforced Security Council demands when the Council was not prepared to expressly authorize force-as in the 1991 efforts to protect Iraqi Kurds after the Gulf war, the 1999 intervention in Kosovo, and the 2003 Iraq war. The disconnect between Security Council mandates and the means to enforce them had begun to erode the Council's authority and effectiveness long before the diplomatic rupture that preceded the 2003 Iraq war, although the discord over Iraq was particularly corrosive.

The diplomatic wounds over Iraq are still deep, even as both sides of the divide have managed to come together on the Security Council to adopt a resolution affirming the authority of the occupying powers with a limited but valuable UN role..$^{59}$ As the scars heal, the Security Council's future role will likely fall somewhere in between the predictions of the pessimists, on the one hand, and the optimists, on the other. ${ }^{60}$ The Security Council will continue to be the main global forum in which states debate how to respond to urgent threats and crises, but whether-and how often-it will be an instrument for forging consensus and not simply

\footnotetext{
${ }^{58}$ See William J. Durch, Keeping the Peace: Politics and Lessons of the 1990s, in UN PEACEKEEPING, AMERICAN POLITICS, AND THE UNCIVIL, WARS OF THE 1990s, at 1-34 (William J. Durch ed., 1996).

${ }^{59}$ SC Res. 1483 (May 22, 2003). The Security Council requested the secretary-general to appoint a special representative for Iraq, who, among other things, would coordinate "among United Nations and international agencies engaged in humanitarian assistance and reconstruction activities in Iraq" and "work [] intensively with the Authority, the people of Iraq, and others concerned to advance efforts to restore and establish national and local institutions for representative governance, including by working together to facilitate a process leading to an internationally recognized, representative government of Iraq." Id., paras. 8, 8(c). Subsequently it has become clear that a number of countries are reluctant to contribute their forces to postconflict reconstruction without express Security Council authorization, and future UN resolutions on Iraq may provide for a more substantial UN role.

${ }^{60}$ For contrasting positions, compare Glennon's pessimistic assessment, supra note 1, with Anne-Marie Slaughter's more optimistic view, supra note 30.
} 
a tool for carrying out diplomatic battles on the world stage remains to be seen. As the world's predominant military power, the United States could benefit in some future cases from the perceived legitimation of that power that a UN Security Council authorization can provide in the eyes of many, but the temptation for France and other Council members to seek to balance U.S. power in the Council will be great and-if not handled pragmatically-may well lead the United States to seek other fora to find support for its policies. It will not be easy to find a constructive modus vivendi.

\section{Revitalizing the Security Council?}

In the long run, the United States has a tremendous stake in a Security Council that is able to address major threats to peace and security. For one thing, threats such as terrorism are transnational in nature and require concerted, coordinated responses. For another, no successor international decision-making body would likely be as supportive of U.S. interests. The Security Council's structure and membership criteria are based on the concept that the body should reflect both power realities and the ability of states to contribute to maintaining international peace and security. ${ }^{61}$ If the United Nations were reinvented today, resentments, political correctness, and the mantra of sovereign equality would produce an institution far less hospitable to U.S. interests than the Security Council. Although the United States increasingly may turn to fora and alliances involving like-minded states-and to more ad hoc arrangements-to address its multifaceted security needs, the benefit of a global institution with an established mandate to address threats to peace and security remains critically important. Pursuing U.S. objectives within the Charter framework can be a "force multiplier" that enhances access to additional military, economic, humanitarian, and political resources and support; and the effective operation of a reinvigorated Charter scheme can be a source of stability that is in U.S. interests. The challenge is to revitalize the Security Council by building on the best impulses of its founders, namely, the recognition that real capacity to act-with force, if necessary-is essential to securing the peace; that flexibility in defining and responding to evolving threats is necessary; and that the fundamental purpose of safeguarding peace and security must be supplemented by a commitment to human rights and self-determination.

One way to begin to revitalize the Security Council in the face of the many admittedly countervailing trends is to refocus the long-running debate over reform of the Council's membership to reflect these aims. In selecting the Council's nonpermanent members, the UN Charter charges the Cieneral Assembly to pay "due regard ... in the first instance to the contribution of Members of the United Nations to the maintenance of international peace and security and to the other purposes of the Organization, and also to equitable geographical distribution." ${ }^{2}$ But, generally, as Edward Luck points out, “[p]leas for the reform of the Security Council stress equity and representation-not effectiveness and responsibility." 63 To address this problem, a new category of nonpermanent, but longer-term, membership could be created involving terms of four or five years. Selection would be based not primarily on geography, but rather on the contribution that the state is prepared to make-in terms of finances, material, and resources or forces for peacekeeping or other enforcement purposes-to the maintenance of peace and security and on the contributions of the member to the other purposes of the United Nations, including the protection of human rights. States that seek these longer-term positions should articulate-concretely - the ways in which they will aim to advance the purposes

\footnotetext{
${ }^{61}$ UN CHARTHR Art. 23(1).

${ }^{62}$ Id. (emphasis added).

${ }^{63}$ Luck, supra note 40 . Reform of the Council is an enormously difficult issue, but it must be tackled with more vigor given the trends that are eroding the Council's effectiveness and credibility. See Princeton N. Lyman, Saving the UN Security Council-A Challenge for the United States, 2000 MAX PLANCK Y.B.UN L. 127.
} 
of the United Nations while on the Security Council, recognizing, of course, that new and unexpected threats to peace and security and challenges to human rights will arise and require innovative responses. Establishing such a category of nonpermanent, but longer-term, Council membership would not necessarily require a Charter amendment, making its realization more conceivable.

\section{CONCLUSION}

The Security Council's impasse over Iraq was a culmination of earlier trends, but it also represents a transitional moment for the international system. Faced with urgent and potentially devastating security threats posed by terrorist networks and by the proliferation of weapons of mass destruction in the hands of dangerous regimes-and the conceivable combination of the two-the need for a revitalized normative and institutional framework governing the use of force is clear. Whether the United States and its allies will be prepared to seize the moment and work together to refine the agreed parameters of self-defense remains to be seen. Whether the French temptation to use the Security Council as a tool to balance American power will be tempered by a more pragmatic approach-and whether the United States will be prepared to work within the Council to forge agreed responses to future security threatsalso remains to be seen. And whether states that aspire to Council membership will be prepared to make the commitments necessary to ensure effective action is also not clear. What is clear, however, is that the normative rules and the enforcement mechanisms of the UN Charter system must be brought better in sync-as the Charter's founders aimed-if the law and institutions governing the use of force established in the Charter are to play a significant role in the difficult, dangerous years ahead.

JANE E. STROMSETH*

- Professor of Law, Georgetown University Law Center, I would like to thank Alan Kreczko, James Schear, and David Wippman for their helpful comments and suggestions, and Elizabeth Keyes for her able research assistance. 